\title{
A Critique of the Ontological Foundation of Leadership in Contemporary Africa
}

\author{
Okolie, Charles Nkem¹, Ogbonnaya, Lucky Uchenna ${ }^{2}$ \\ ${ }^{I}$ Department of Philosophy, Federal University Ndufu Alike-Ikwo, Nigeria \\ ${ }^{2}$ Department of Philosophy, University of Calabar, Calabar, Nigeria
}

\begin{abstract}
This paper posits that the ontological foundation of leadership in contemporary African countries is Western ontology, which is individualistic. This Western ontology is an imposition on Africans and Africa, through Western colonialism and education. As a result of this Western individualistic ontological foundation, most contemporary African political leaders see political power as a means for self aggrandizement. Thus, with this mindset, African leadership has become more self-centred instead of national-centred. This is contrary to the traditional African way of life which is communal. The paper therefore alludes to African ontology as the possible way out of the problem of bad leadership that Africa is facing today. This ontology is chosen because it is communal and religious in nature. Through it, African leaders will be made to realize that national interest comes before individual interest. This paper avers that for Africans to have this kind of mindset that embraces others, they need to undergo what Asouzu calls 'existential conversion', through a process called 'noetic propaedeutic'- re-education of the mind. This paper employs critical reflection and synthetic analysis to arrive at its conclusion.
\end{abstract}

Keywords: Existential Conversion, Leadership, Noetic Propaedeutic, Ontology

\section{INTRODUCTION}

Africa as a continent is chiefly plagued with the problem of leadership. African leaders are the reason for what Africa and Africans are today. Rather than move Africa forward African leaders have helped to make Africa useless and nothing to write home about in world history. This problem of leadership is so bad that a famous Nigerian novelist by name Chinua Achebe (1984) has to note using Nigeria as a case in point that

The trouble with Nigeria is simply and squarely a failure of leadership. There is nothing basically wrong with the Nigerian character. There is nothing wrong with the Nigerian land or climate or water, or air or anything else. The Nigerian problem is the unwillingness or inability of its leaders to rise to the responsibility, to the challenge of personal example which are the hallmark of true leadership. (1)

This problem of leadership is not peculiar to Nigeria. It is the problem of the entire African continent. African leaders have refused to be responsible; they have refused to lead by example. They are leaders that are corrupt and nepotic as well as tribalistic. This kind of leadership is in turn destroying the unity of many countries in Africa. Worst still is the issue of leaders looting from the national purse due to self-centredness against national interest.

One may ask: what is wrong with African leaders and leadership? The answer simply lies in the fact that African leaders are not operating under the influence of African traditional values that shuns corruption and eschew individualism. African leaders are under the influence of Western individualism that came in with Western education rooted in Western ontology. It is this ontology that has informed the high level of failure of leadership in Africa. This is simply because corruption is now applauded than shunned. It is indeed a situation that needs to be remedied.

This paper therefore seeks this remedy in African ontology that is communal in nature. The reason is that this ontology promotes the community interest above personal interest. It makes the individual to be conscious of the fact that he/she is in service to the community of beings. This ontology also 
inculcates in the minds of Africans that their leadership life have a religious dimension that must be taken seriously. It is this ontology that the African need against the Western ontology that has helped to destroy our being as Africans.

\section{THE ISSUE OF LEADERSHIP IN CONTEMPORARY AFRICA}

Leadership as found in African today is one that is characterized with a lot of ills and vices. African leaders are leaders that have failed the African states in almost all aspects of the African being and existence. African political leaders are far from what is expected of any leader in the world. These leaders lack the discipline that is required for leadership. This is probably due to the manner and way through which they were being brought into power or position of authority. It is apparent that many (if not all) of African leaders today came into power through the wrong means, and not because they are competent or qualified for such an elevated position. N. S. S. Iwe (1984) captures this thus:

Often appointments are not based on evident competence and merit. The vested interests of the appointing authorities account far more than other factors. The common practice is to buy your way up to the position of authority. Having reached the coveted position, the incumbent begins to regard his office as an inherited divine right. They can be no question of the resignation from office, even in the face of obvious gross misconduct or of evident general dissatisfaction. Gross ineptitude and incompetence in office or highly questionable public probity of the incumbent are no obstacle to tenure of office here in Nigeria and other part of West Africa. (73)

Although Iwe restricts himself to Nigeria and West Africa, this is the case in almost all African countries. Almost all of African leaders are incompetent and lack the moral and intellectual capacity to manage and man the affairs of the state. It is probably due to this that the African states are going through a lot of crises - economic (financial), political, and social disorder. This is a great leadership failure.

African leaders, in various African countries that are in tumour, instead of thinking about a possible solution to these social malaises confronting their states (nations), rather think about institutionalizing themselves in the offices they presently occupy. They do not care if the nation disintegrates or if the masses die of hunger and starvation. All they are after is themselves - their own interest. The problem as stated earlier lies in the way African leaders are today bought into office. This people are usually those that lack a sense of what they want to achieve in office since they are intellectually incapable driving the nation to its expected end other than to serve their interest and the interest of those who tele-guided them into office (Ochulor 2010:2). This is indeed a true picture of Nigeria and other African nations. African nations are manned by incompetence leaders, who cannot stand up to the challenges that confront them and their countries. They rather think of what to gain from their opportunity in the offices they find themselves.

This connotes that African leaders only come into position of authority in order to enrich themselves rather serve the national interest. They see politics and political office as means to the national cake, as they loot massively from the national treasury, not minding if the nation becomes bankrupt and financially incapacitated. Chinenye Ochulor (2010) buttresses this point in the light of Nigerian political scenario, which is typical of an African nation, as he avers that "[m]any Nigerians have this spoils view of politics and political activities. That to a large extent accounts for the abuses in government offices we daily experience in the country" (3). This people use their office to create and make secret illegal profits. The truth is that they see politics and political power as a path to the about national cake. This is the 'politics of national cake'. With this national cake mentality, almost all Africans want to go into politics in order to get their own share of the national cake. Many of our African politicians are not really interested about their contributions towards the national growth of their countries; rather they are after how their personal accounts will grow fatter by the day. It is exactly this kind of picture that Thrasymachus in Plato's Republic (1941) tries to paint as he addressed Socrates about political leaders. According to him, "[w] hy you imagine that a herdsman studies the interest of his flock and cattle, tending and fattening them up with some other end in view than his master's profit or his own; and so you don't see that in politics" (Bk. 1: Ch. 343). What 
Thrasymachus is saying is that in politics leaders are not after the welfare those under their care like "the genuine ruler regards his subject exactly like sheep and thinks of nothing else, night and day but the good he can get out forhimself" (Bk. 1: Ch. 343).

Apart from African politicians being self-centred, they also see political office as a means of meeting the demands of their immediate community, friends, family and ethnic group. By this, one is saying that African leaders are ethnocentric - they think about their immediate relatives and communities first before even the national interest, which they are supposed to promote. In this way, they are operating under what Asouzu calls "the super-maxim" - "the nearer the better the safer" (2007a, 19). It is this kind of mindset that instigates African leaders to loot from national purse or treasury, in order to satisfy the demands of their relatives, communities and ethnic groups. This is due to the fact that their people see their being in such political office as a blessing that must be utilized for their own good. Ochulor (2010) reiterates this by saying that

People, villages, towns and communities whose sons and daughters are in government departments often make demands of them; such demands that can only be met by a corrupt use of one's office. If the demands are met, such incumbents become darling-sons of the soil. If they do not respond favourably, they are dubbed big fools. They will be treated with contempt and all kinds of calumny are rained upon them. With distorted attitude, we Nigerians in one way or the other compel our leaders to loot the public treasury. It is not surprising then that once a town has someone in government, it undergoes rapid transformation, depending on the person's office and its tenure. (4)

It is therefore this situation that brings "greed and apathy which lead to misrule which in turn leads to lack of patriotism" (Ochulor 2010, 5) among leaders.

There is widespread failure in contemporary leadership in Africa. This can be seen in the quenchless desire and quest of leaders for power and their determination to remain in positions of authority, regardless of the state of the nation and the cry of the people. Due to the corrupt nature of the leaders, the society too is affected and infected with corruption. This is in line with an African adage that says 'when the head is bad the entire body will also be bad'. It is about this degraded state of Africa that Chike Ekeopara (2014) notes:

The litany of social ills in contemporary African societies is endless. Moral bankruptcy has given rise to numerous cases of ritual killings, incest, child abuse, marital infidelity and divorce, disorder and armrobbery, kidnapping, dishonest living and the famous 419 of OBT (obtaining by tricks). (146)

Hence, the nations of Africa are true picture of our failed and corrupt leadership or leaders. No nation is above her leaders. We are what our leaders are. Africans are now corrupt and self-centred as well as self-seeking. They is no more national interest driving Africans, it is all about personal interest. What a poor state of a continent!

\section{An Appraisal of the Ontological Foundation of Leadership in Contemporary Africa: The Need for a Return to African Ontology}

From the foregoing discussion, it is apparent that the ontology that drives African leadership today is Western ontology. This ontology is individualistic and not communal. This is an ontology that sees an individual entity or reality as complete in itself and capable of existing without others. This is glaring in the metaphysics of Aristotle (1947). This very revered Western scholar proposed and put forward an ontology that is bifurcating and polarizing, as he argues that being consists of substance and accident but goes ahead to equate substance with being. He sees substance as that which can exist without accident, but that accident cannot exist without substance. Thus, it is substance which is selfsubsisting that is being. In his words, "if there are not substance, there is no substance and no being at all; for the accidents of these it cannot be right to call" (Book B, 5).This ontology emphasizes substance above accident. This idea has been replete in a lot of thoughts put forward by subsequent Western philosophers that came after Aristotle.

For instance, Thomas Aquinas following Aristotle also notes that it is substance that can be equated to being. He further sees this Aristotle's substance as spirit and posits that spirit is that which is synonymous with being or reality. It is this type of ontology that coloured the rationalists and 
empiricists battle on what really constitute reality. While the rationalists posits that it is the immaterial aspect of being that constitute reality, the empiricists aver that it the material aspect of being that is real. Thus, each of these groups holds that it is either the material or immaterial substance that is real. Worst still is Hegel's view that it is only absolute spirit that exists. This absolute spirit could be what Heidegger calls the Daisen - the human being (being with others). This being is that being through which other beings could be known. It invariably affirms the existence of other beings. This being is not different from Sartre's being-for-itself, which is a conscious being (1958, ix). This being is what exists and defines the fate of other beings that it sees as unconscious - being-in-itself. The conscious being is the human being, the Daisen of Heidegger and the absolute spirit of Hegel as well as the spirit of Aquinas and substance of Aristotle.

It is this one-sided metaphysics or ontology that the Westerners have lived with as well as relate with other people of the world and in particular Africans. They believe that they are the only ones that count and Africans do not. It is in this manner that they related with us - Africans, when they came and colonized us. It is this same bifurcating and polarizing mindset that they bequeathed to our leaders that took over from them. They showed them that the people that they are leading do not count and that all that counts is themselves. Chris Akpan and Lucky Ogbonnaya (2013) have used Sartre as a case in point to illustrate how Western ontology colours African leaders' relationship with the led. According to them,

Sartre's ontology can also be seen as probably the principle underpinning the relationship between the leaders and the led especially in Nigeria. Here, the leaders by implication may be said to be the being for-itself which are conscious. These leaders see themselves as superior and should decide for the led which are inferior and without anything to offer. They are the masters who dictate for the slaves. (146)

It is with this Western beclouded ontological mindset that African leaders today administer the states or nations they find themselves. They see themselves as the all in all.

In the very spirit that without them others are nothing and that they are the ones that define the nation as well as what is and what is not, they choose to act the way they act. It is in this light that they choose to institutionalize themselves within the corridors of power and would want to do anything to remain in position of authority. This is simply because they see themselves as the Aristotle's substance, Aquinas' spirit, Hegel's absolute spirit, Heidegger's Dasein and Sartre's being-for-itself. It is due to this that they (African politicians) see themselves as the all in all as well as the determining factor in the political arena and society.

With this mindset, African leaders begin to loot from the national purse to the detriment of the nation. They, at this point, see their interest as what suffice because of the belief that without them no one is relevant. They are at the centre stage and should decide what goes to who! African leaders that have grown with this Western ontological mindset do not regard others as anything. This, for Asouzu, is due to ihe mkpuchi anya (phenomenon of concealment) (Ibuanyidanda ... and Some 12). They are, by this, veiled with their personal concern even to the detriment of the nation they man as leaders. Thus, they see no one and nothing other than themselves and their self-interest. This greatly accounts for the tremendous increase in the wealth of politicians and the heavy indebtedness of many African nations. What an irony that politicians are rich, while the country is in poverty. This very idea that the politicians are the only ones that matter in most African countries negates the African communal spirit. It follows strictly the Western individualism that makes individual more relevant than the community.

It is on this premise that a politician can do anything in order to gain any political position. They do not mind killing people, whom for them do not matter just to have political power. This, to a great extent has informed political thuggery, hooliganism, assassinations and killings targeted at political opponents. It is worthy of note that those that are majorly used by these politicians to carry out these crimes in the society are the worthless in the society. There are: the Aristotle's accident, the Aquinas' matter, and the Sartre's being-in-itself. They are those who can be discarded from the society, since they have no relevance other than to serve in this kind of positions that are inconsequential to the society. These so-called good for nothing group of persons are those that are used and abandon by the political class, who see themselves as the personification of their society. 
Even among the political class, there is open rivalry. This is because every politician will want to outshine the other; and in a situation where they are vying for the same office, they may go all out to see that they render their opponents useless. This is indeed a great level of individualism that is informed by Western bifurcating and polarizing ontology. Thus, among these rival politicians, there is always the agitation for a particular group or individuals to see themselves as Aristotle's substance, Aquinas' spirit and Sartre's being-for-itself and their opponents as Aristotle's accident, the Aquinas' matter, and the Sartre's being-in-itself. They can even go all out to do away with them in order to win their goal.

It is germane to state that this problem of leadership in contemporary Africa that has its root in Western ontology is not restricted to individualism or the promotion of individual interest. It also has ethnic and religious undertones. Those who are opportune to be in any political office see it as an opportunity to serve the interest of their ethnic or religious group. This is simply because they see their ethnic or religious group as superior to others. They therefore seek after the interest of their ethnic or religious affiliation. This is probably informed by their view that they are Aristotle's substance, Aquinas' spirit and Sartre's being-for-itself and members of other ethnic and religious group are the Aristotle's accident, the Aquinas' matter, and the Sartre's being-in-itself. This has lead to a lot of violent clashes within African nations. A case in point is the crises in northern parts of Nigeria which have both ethnic and religious undertones. African leaders are after their individual interest as well as the interest of their ethnic or religious affiliation to the detriment of the nation; and can sacrifice the national interest in order to meet the interest of their ethnic or religious group.

Thus, "daily, the proliferation of social crimes and the unbearable conditions of human life cloud the future with a notable gloom and beak" (Ekwuru 1999, 8) in many African countries. It is on this premise that it can be said that politics and leadership are all "about satanic cunningness, craftiness, ruthless maneuvering and unvarnished power display" (Ozumba 2005, 112) as well as enriching of individuals and families (foreign) bank account or the boosting of ethnic and religious power and relevance in the country. Also,

selfishness and avarice have become the order of the day because African drunk in Western cultural habits, no longer respect or obey traditional ethical norms and values. Commununal solidarity of the pristine times have given way to individual solidarity and mindedness. The spirit of community is strength ('umumawuike') as the Igbo would say has been replaced with wealth is strength ('akuwuike'). Individuals commit crime of using their brothers, sisters, mothers, fathers, kinsmen and even their children for rituals, instead of protecting them from harm. (Ekeopara 2014, 146)

Iniobong Umotong elaborates this point as well as blamed the situation to the lost of African traditional values, as he asserts the coming of Christianity and Islam has led to the wrong way of bringing leaders into office. It is no longer based on the will of the gods or hereditary or military courage or moral uprightness in line with African values "but by financial influence (rightly or wrongly acquired) as such there is no name to protect in being unjust and unfair in their dealing with the people" (244). This is brought about by Western ontology which came to the Africans through Western education, indoctrination, and socialization. This has indeed led to a great deal of corruption among African nations, due to the individualistic mentality that this ontology has registered in the minds of African leaders. It is this scenario that instigates the need for African ontology, as the way out of this socio-political problem, which has an ontological undertone.

African ontology is the African notion of being. It is a picture of the African conception of beings and their interaction with one another. By this, "African ontology holds that beings exist in community" (Ekeopara and Ogbonnaya 2014, 38). It is because beings exist together that they interrelate and interact with one another. According to Placide Tempels, the Africans hold that beings relate with one another through their vital force $(1959,59)$. And that it is this vital force that determines the positions of being in African hierarchy of beings. Francis Njoku gives a graphical representation of African hierarchy beings as follows: God, spirit of ancestors, humans, animals, plants, and inanimate objects $(2002,18)$. Explaining this further Chike Ekeopara and Lucky Ogbonnaya (2013) aver that 
Those beings that are higher in the hierarchy of beings exert more force on those below them. Thus they can bring calamity and disaster on those beings below them who defile the moral law or principles. It is this consciousness that causes the Africans to live in fear of the spiritual beings that are above them in the hierarchy of beings. (3839)

This kind of ontology is a religious ontology, since it sees the human being as a being that relates with the Supreme Being and divinities as well as ancestors. Leaders are found under the influence of the Supreme Being and divinities as well as ancestors, who have delegated leadership to them. Thus, if there is failure in the part of leaders to administer any African nation or state appropriately, these higher beings will bring calamity on the leaders and the land in which they find themselves. Umotong (2012) buttresses this point thus: they rulers therefore administer their office with the fear of the goods. This is because of the consciousness that any art misrule will bring calamity upon the entire land beginning with them and their family or household. Hence, "[t]he fear of being punished by the gods or the wrath of the gods rekindled upon the entire community was the order of the day as such governance was seen as a service not only to humanity but unto the gods" (246). This, therefore, makes African ontology an ethical ontology. This ontology set up the ethics that should guide African leadership. This ethics is an ethics of fear of these superior beings that exact greater vital force over humans that are under their influence and service. With this kind of ontology, one is always afraid of embezzling public fund or contesting for an office that he/she is incapable of handling. That is to say, everyone seeks to lead an upright life in any position he/she is called to serve else incur the wrath of the Supreme Being or gods.

Apart from African leaders living up to expectation because of the fear of the Supreme Being and gods, they can also live an upright life devoid of corruption and bad leadership because of the communal nature of the ontology. C. M. Okoro (2008) buttresses this point as he assert that it takes them away from the individualistic mindset that at present drives their selfish actions and lifestyle. This is because "[i]t has the we-spirit of African traditional political philosophy to offer particularly to the contemporary African leaders whose leadership style tends to the philosophy of one man's show or solipsism" (43). This we-consciousness or community-consciousness does not allow anyone to rob the national treasury for any reason. Rather every leader thinks of what he/she can contribute to the betterment of the nation. This ontology does not give room for self-centredness but for the common good or national interest, which is regarded as a higher good.

Another point to note about African ontology is that it seeks to harmonize and unify entities or realities within being. This ontology holds that, spirit and matter co-exist as one within being. It also posits that substance and accident are in mutual complementary relationship within a whole called being. By implication, if spirit and substance are seen as leaders and matter and accident are taken to be the led or the masses, none can be said to be superior or inferior. This is premised on the fact that they always exists as inseparable units of the society. Hence, if the leaders regard the led as inferior and inconsequential who then will they lead if the led all die due to starvation or lack of basic amenities of life. With this kind of ontology, African leaders will come to realize that they need the led to remain relevant, and that they need to seek the interest of the whole which they and the led are part of. Thus, the leaders in contemporary Africa can become people who are society-oriented only if they imbibe this African ontology that is inclusive and communal in nature.

This is only possible if only African leaders must overcome ihe mkpuchi anya (phenomenon of concealment) (Asouzu, 2007a, 233), which beclouds them from seeing above their personal interest or that of their immediate ethnic or religious groups. They can overcome this phenomenon through what Asouzu calls 'existential conversion'. Through existential conversion the individual tends to seek to attain unity, totality, and whole in a future referential manner with other missing links of reality (Asouzu, 2004, 312). By implication, existential conversion is a process that can help African leaders to realize that others are missing links to them and that they should not be used and discarded. But that they should take them as part of their being for efficiency in office since true self-authentication comes through the opposite other (Asouzu, 2003, 82), hence African leaders should take into consideration seriously their opposite other and that is the led. This is because they are the ones that make their office or position relevant. It is when leaders become able to see others as important as themselves that they can treat them well without looting from the national treasury. It is at this state 
that we can say that African leader have come into full autonomy - a full act of self-consciousness (ima onwe onye) (Asouzu, 2007a, 297, 298), since they are no longer under any foreign influence and are able to handle their existential situation carefully without thinking of themselves above others or the larger community.

It is worthy of note that what can lead us to the process of existential conversion is what Asouzu sees as 'noetic propardrutic' (pre-education of the mind) (2013b, 30). It is this education that can help the minds of African leaders purge out all forms of Western indoctrination that is rooted in Western individualistic ontology. It is this education that can make Africans realize that they are being-withothers; and that without other members of the society they are irrelevant. That is to say, an individual's relevant is only realized through the other and the community. It is this kind of communitarian ontology that can lead to good leadership in Africa.

\section{CONCLUSION}

Indeed African leadership today is one that is coloured with corruption that stems from individualism. This has its root in Western ontology that is antithetical to African ontology that is communal. It is this individualistic ontology that has made African leaders to see their position as means of enriching themselves and serving their immediately ethnic or religious group. Situations like this have led to power tussle and lose of lives. It has led to a high level of dehumanizing of those that are not in leadership position. But this ought not to be the case since Africans live in community.

Thus, this paper has called our attention to the need to return to our traditional African ontology, which is religious and ethical as well as promotes values that lead to efficient leadership. This is because it gives one the sense of existing with other beings that have influence on our being. It is an ontology that engraves in our consciousness the fact that we are to serve one another and even spiritual beings that give us the opportunity to serve in any office that we find ourselves. And that failure to remain morally upright will receive immediate punishment. This is therefore the kind of ontology that can help bring back the Africa and Africans that our fore-parents knew and enjoyed. All hope is not lost. We can still have good leaders and leadership in Africa. This will be possible only when we undergo existential conversion through noetic propaedeutic that involves a re-educating of our minds to start thinking as Africans with the community at heart rather than our selfish interest.

\section{REFERENCES}

Achebe, Chinua (1984). The Trouble with Nigeria. Essex: Heinemann.

Akpan, Chris O. and Lucky U. Ogbonnaya (2013). "Between Sartre's Cat and Mouse Ontology and Asouzu's Ibuanyidanda: How not to Implore Interpersonal Relations". America Journal of Social Issues and Humanities. 3.3. 140-141.

Aristotle (1947). Metaphysics. Trans. W. D. Ross. Oxford: Clarendon.

Asouzu, Innocent I. (2003). Effective Leadership and the Ambivalence of Human Interest: The Nigerian Paradox in a Complementary Perspective. Calabar: University of Calabar.

Asouzu, Innocent I. (2012). Ibuanyidanda and the Philosophy of Essence (Philosophy, the Science of Missing Links of Reality). 50 ${ }^{\text {th }}$ Inaugural Lecture, Calabar: University Calabar.

Asouzu, Innocent I. (2013). Ibuanyidanda (Complementary Reflection) and Some Basic Problems in Africa. Zurich: Lit Verlag GmbH and Co. KG Wien.

Asouzu, Innocent I. (2007). Ibuanyidanda: New Complementary Ontology, Beyond WorldImmanentism, Ethnocentric Reduction and Imposition. London: Transaction.

Asouzu, Innocent I. (2013). Ibuanyidanda (Special Edition): Excerpt from Online Dictionary of Intercultural Philosophy. (ODP). Calabar: University of Calabar.

Asouzu, Innocent I. (2007). Ibuaru: The Heavy Burden of Philosophy Beyond African Philosophy. London: Transaction.

Asouzu, Innocent I. (2004). The Method and Principles Complementary Reflection in and Beyond African Philosophy. Calabar: University of Calabar.

Ekeopara, Chike (2006). "Traditional Ethics and Social Stability: The African Experience". Sophia: An African Journal of Philosophy. 9. 1. 143-147.

Ekeopara, Chike and Lucky Ogbonnaya (2014). "Traditional Ethics and the Maintenance of Social Order”. European Scientific Journal. 10. 29. 34-46. 
Ekwuru, George E. (1999). The Pangs of an African Culture in Travail. Owerri: Totan.

Iwe, N. S. S. (1984). "The Reality of the Nigerian Social Scene Selfishness". AMAN: Journal of Society, Culture and Environment. 3. 2. 71-80.

Njoku, Francis (2002). Essays on African Philosophy, Thought and Theology. Owerri: Clarentian Institute.

Obiajulu, Mulumba I. (2015). "The Question of Moral Paradigm in African Philosophy: A Case for Communocentric Ethics". Atuolu Omalu: Some of the Unanswered Questions in African Philosophy. Ed. Jonathan Chimakonam. Maryland: University Press of America. 53-66.

Ochulor, Chinenye Leo (2010). "Failure of Leadership in Nigeria". Sophia: An African Journal of Philosophy. 12. 2. 1-7.

Okoro, C. M. (2008) "Appraisal of African Concept of Being”. Philosophy and Praxis: Journal of Nigerian Philosophical Association. 4. 30-53.

Ozumba, Godfrey (2005). "Reconstructing Nigerian Leadership through Philosophical Enterprise". Sophia: An African Journal of Philosophy. 7. 2. 106-113.

Plato (1941). The Repulic. London: Oxford University.

Sartre, Jean-Paul (1958). Being and Nothingness. Trans. Hazel E. Barnes. Introduction by Mary Warnock. London: Methuen.

Tempels, Placide (1959). Bantu Philosophy. Paris: Presence Africane.

Umotong, Iniobong (2012). "Religious Factor in African Politics". African Political Philosophy. Eds. Godfrey Ozumba and Elijah John. Uyo: El-johns. 237-249. 